\section{Effects of Preplant Nitrogen and Sulfur Fertilizer Sources on Strawberry}

\author{
Bielinski M. Santos ${ }^{1}$
}

AdDitional InDEX wORDs. Fragaria $\times$ ananassa, ammonium sulfate, slow-release, best management practices, crop nutrition

SUMMARY. Field studies were conducted to determine effects of preplant nitrogen $(\mathrm{N})$ and sulfur $(\mathrm{S})$ sources on 'Strawberry Festival' strawberry (Fragaria $\times$ ananassa) growth and yield. Six treatments resulted from the preplant application of ammonium nitrate [AN (34\% N)], ammonium sulfate [AS $(21 \% \mathrm{~N}$ and $24 \% \mathrm{~S})$ ], ammonium sulfate nitrate [ASN $(26 \% \mathrm{~N}$ and $14 \% \mathrm{~S})$ ], polymer-coated AS [PCAS $(20 \% \mathrm{~N}$ and $23 \% \mathrm{~S})]$, and elemental $\mathrm{S}(90 \% \mathrm{~S})$. A nontreated control was added. The $\mathrm{N}$ was fixed at $50 \mathrm{lb} /$ acre for AN, AS, ASN, and PCAS, which resulted in $\mathrm{S}$ rates of $0,57,27$, and $57 \mathrm{lb} /$ acre, respectively. The $S$ rate of the elemental $S$ treatment was set at $57 \mathrm{lb} /$ acre. For early fruit number, the highest values were found in plots treated with AS and elemental $S$, while the highest total fruit numbers were obtained in plots treated with AS, ASN, PCAS, and elemental S. There was no difference in total fruit numbers between the nontreated control and AN. Plots treated with elemental S, PCAS, ASN, and AS had the highest early marketable fruit weights, whereas the lowest early marketable fruit weight was found in the nontreated plots. In comparison with the nontreated control plots, all the preplant fertilization programs improved early marketable fruit weight, with AN, AS, ASN, PCAS, and elemental S. Total marketable fruit weights were maximized in plots treated with preplant AS, ASN, PCAS, or elemental S. There was no difference between the total fruit weights obtained in the control and AN-treated plots. The data indicated that the strawberry total yield increases can be attributed to the use of preplant fertilizer sources containing $S$. This research may lead to a more appropriate use of $\mathrm{N}$ for strawberry production in Florida, minimizing the nitrateleaching potential in high sandy soils by eliminating $\mathrm{N}$ sources from preplant fertilization programs.

S trawberry is one of the most important small fruit crops throughout the world. The United States, Spain, and Canada annually plant around 55,000, 17,000, and 10,000 acres, respectively (Food and Agriculture Organization of the United Nations, 2008). Florida has the second largest production value in the United States, which generated in 2007 nearly $\$ 330$ million in 8300 acres (U.S. Department of Agriculture, 2008). Most of Florida's acreage is established under the annual hill system in which raised planting beds are fumigated for soilborne pest control, irrigated with drip lines, and covered with polyethylene mulch. The vast majority of strawberry production occurs in the westcentral part of the state, where sandy soils with rapid infiltration, very low organic matter, and high water tables are the norm.

Assistant Professor of Horticulture, Gulf Coast Research and Education Center, IFAS, University of Florida, 14625 County Road 672, Wimauma, FL 33598

I thank Honeywell financial and logistic support for this research.

${ }^{1}$ Corresponding author. E-mail: bmsantos@ufl.edu.
The nutrient-leaching potential of these soils is relatively high, which has important environmental and crop production implications. From the environmental standpoint, nitrate leaching to groundwaters is one of the main causes for river and lake eutrophication and subsequent changes in aquatic life (Finkl and Charlier, 2003; Florida Department of Environmental Protection, 2008; Florida Springs Task Force, 2000). In many bodies of water across Florida, nitrate levels have increased 2- to 3-fold over the past 20 years, reflecting the close link between surface and groundwater (Florida Department of Environmental
Protection, 2008). One of the main sources of high nitrate concentrations in groundwaters is agricultural fertilizers. Therefore, appropriate $\mathrm{N}$ fertilization programs are needed to support the current best management practice efforts in the state. Informal surveys among strawberry growers in westcentral Florida indicated that as much as $50 \mathrm{lb} /$ acre of $\mathrm{N}$ are preplant incorporated and that about one-third of the acreage still uses this practice (B.M. Santos, unpublished data).

Previous research has shown the diverse effects of preplant $\mathrm{N}$ practices and sources on strawberry production. Albregts et al. (199la) showed that the use of preplant fertilizer on strawberry may not enhance fruit yields and quality, or plant size, if sufficient fertilizer is supplied by the drip irrigation system as soon as the plant roots are able to absorb it. Hochmuth and Cordasco (2009) indicated that the crop will benefit from split applications of preplant and drip-injected fertilizers, which resulted in $10 \%$ higher yields, $12 \%$ more early fruit, and $5 \%$ larger fruit, compared with yields of plots treated with only preplant fertilizer. With regard to $\mathrm{N}$ sources, Locascio and Martin (1985) found that when $100 \%$ of the $\mathrm{N}$ was applied before planting, strawberry marketable fruit number and weight were significantly greater with sulfur-coated urea than with urea, ammonium nitrate (AN), and calcium nitrate. Other research suggested that total marketable fruit yield did not vary because of preplant applications of sulfur-coated urea, $\mathrm{AN}$, and urea in strawberry (Albregts et al., 1991b). Santos and Whidden (2007) reported that there was no strawberry total yield difference between the preplant application of 50 $\mathrm{lb} /$ acre of $\mathrm{N}$, using $\mathrm{AN}$ as the $\mathrm{N}$ source, and the nontreated control.

In spite of all these dissimilar reports, the nature of the $\mathrm{N}$ source

\begin{tabular}{llll}
\hline $\begin{array}{l}\text { Units } \\
\begin{array}{l}\text { To convert U.S. to SI, } \\
\text { multiply by }\end{array}\end{array}$ & U.S. unit & SI unit & $\begin{array}{l}\text { To convert SI to U.S., } \\
\text { multiply by }\end{array}$ \\
\hline 0.4047 & acre(s) & $\mathrm{ha}$ & 2.4711 \\
0.3048 & $\mathrm{ft}$ & $\mathrm{m}$ & 3.2808 \\
9.3540 & gal $/ \mathrm{acre}$ & $\mathrm{L} \cdot \mathrm{ha}^{-1}$ & 0.1069 \\
2.54 & inch(es) & $\mathrm{cm}$ & 0.3937 \\
1.1209 & $\mathrm{lb} / \mathrm{acre}$ & $\mathrm{kg} \cdot \mathrm{ha}^{-1}$ & 0.8922 \\
25.4 & mil & $\mu \mathrm{m}$ & 0.0394 \\
28.3495 & $\mathrm{oz}$ & $\mathrm{g}$ & 0.0353 \\
0.9072 & ton $(\mathrm{s})$ & $\mathrm{t}$ & 1.1023 \\
2.2417 & ton/acre & $\mathrm{t} \cdot \mathrm{ha}^{-1}$ & 0.4461
\end{tabular}


may play a significant role on nutrient mineralization, absorption, and leaching in vegetable and small fruit crops. The amount of released $\mathrm{N}$ varies markedly due to weather and other factors (Fixen and West, 2002). The overall $\mathrm{N}$ use efficiency of a cropping system can be increased by achieving greater uptake efficiency from applied $\mathrm{N}$ inputs by reducing the amount of $\mathrm{N}$ lost from soil organic and inorganic $\mathrm{N}$ pools, or both (Cassman et al., 2002). Guertal (2000) showed that slow-release $\mathrm{N}$ materials had no consistent higher yield advantage over a soluble $\mathrm{N}$ source in bell pepper (Capsicum annumm). However, the same author indicated that if a yield benefit is not widely demonstrated, some other benefits may justify using slow-release fertilizers, such as reduced $\mathrm{N}$ leaching, increased $\mathrm{N}$ use efficiency, and decreased production costs (Guertal, 2009). Thus, it is important for the economic and environmental sustainability of the strawberry production system to access the appropriate utilization of soilapplied $\mathrm{N}$ sources.

Sulfur $(S)$ is an essential plant nutrient required for the synthesis of the amino acids cysteine and methionine, proteins, and enzymes. It has been shown to play an important role in yield and quality of crops (Heeb et al., 2006; Pavlista, 2005; Rhoads and Olson, 2000). This element occurs in the soil in organic and inorganic forms. In most soils, over $90 \%$ of $\mathrm{S}$ is in the diverse organic forms (Tabatabai, 1984). The majority of plants absorb $S$ through the roots in the inorganic sulfate $\left(\mathrm{SO}_{4}\right)$ form, although limited amounts can be absorbed through the leaf stomata as the gas form $\mathrm{S}$ dioxide $\left(\mathrm{SO}_{2}\right)$. Because the deep Spodosols of westcentral Florida have reduced organic matter content, natural organic and inorganic $S$ contents are also low. In the past, $S$ was supplied indirectly through other fertilizers such as triple superphosphate and deposition from the atmosphere. However, during the past two decades, as the composition of fertilizers changed to high-analysis and $S$-free products, crop production intensified, and $\mathrm{SO}_{2}$ emissions decreased, $\mathrm{S}$ deficiencies have become a serious problem (Ceccotti et al., 1998).

It has been suggested that to achieve high yields and to minimize
$S$ leaching, rates of $S$ fertilizer should be recommended on the basis of available soil $S$ and crop requirements (Scherer, 2001). A previous tomato (Solanum lycopersicum) study found that $S$ sources (ammonium sulfate vs. ammonium thiosulfate) had similar effect on yields (Susila, 2001). The same study determined that fine sandy soils were inefficient in supplying enough $S$ for 6 weeks of growth, and preplant application of $S$ produced lower leaf $S$ concentrations than in those treatments where $S$ was applied through drip (Susila, 2001). More studies are needed to confirm those results and to compare the effect of S sources in other crops, including strawberry. The objective of this study was to determine effects of preplant $\mathrm{N}$ and $\mathrm{S}$ sources on strawberry growth and yield.

\section{Materials and methods}

Two trials were conducted during the 2007-08 and 2008-09 strawberry seasons at the Gulf Coast Research and Education Center of the University of Florida, located in Balm, FL. The soil at the experimental site is classified as a Myakka fine sand siliceous hyperthermic Oxyaquic Alorthod. The organic matter content and the soil $\mathrm{pH}$ were $1.5 \%$ and 7.3 , respectively, and were measured 4 weeks before transplanting from random samples collected in six locations within the experiment site. For organic matter and soil $\mathrm{pH}$ determination, the Walkley-Black and 1:2 soil-to-water methods were used, respectively (Mylavarapu, 2009). Planting beds were 27 inches wide at the base, 24 inches wide at the top, 10 inches high, and spaced $4 \mathrm{ft}$ apart on centers. In mid-September of each season, pressed beds were fumigated with methyl bromide plus chloropic$\operatorname{rin}(67: 33, \mathrm{v} / \mathrm{v})$ at a rate of $350 \mathrm{lb} /$ acre to eliminate soilborne diseases, nematodes, and weeds in the soil. A standard fumigation rig with three knives per bed delivering the fumigant 8 inches deep was used. Within 1 min of fumigation, beds were covered with black high-density polyethylene mulch ( 0.7 mil thick), and a single line of drip irrigation tubing (25 gal/acre per min; T-Tape Systems, San Diego) was buried 1 inch deep on bed centers.

Six treatments resulted from the preplant application of $\mathrm{AN}(34 \% \mathrm{~N})$, ammonium sulfate (AS; $21 \% \mathrm{~N}$ and $24 \%$ S), ammonium sulfate nitrate (ASN; 26\% N and 14\% S; Honeywell, Morristown, NJ), polymer-coated AS (PCAS; $20 \% \mathrm{~N}$ and $23 \% \mathrm{~S}$, Honeywell), or elemental S (90\% S). A nontreated control was added (Table 1 ). The $\mathrm{N}$ was applied at $50 \mathrm{lb} /$ acre for AN, AS, ASN, and PCAS, which resulted in $S$ rates of $0,57,27$, and $57 \mathrm{lb} /$ acre, respectively. The $S$ rate of the elemental $S$ treatment was set at $57 \mathrm{lb} /$ acre. Two weeks after fumigation, beds were uncovered and measured amounts of each preplant fertilizer source were spread on bed tops and incorporated on the 2 inches of the soil with garden rakes. Immediately after, beds were recovered with the same mulch as previously described. During all the seasons, treatments were established in a randomized complete block design with six replications. Experimental units were $12.5 \mathrm{ft}$ long ( 20 plants per plot).

Table 1. Effects of preplant nitrogen (N) and sulfur (S) sources on strawberry plant canopy diameter at 4 and 12 weeks after transplanting (WAT), and leaf greenness at 12 WAT in 2007-08 and 2008-09 at Balm, FL.

\begin{tabular}{|c|c|c|c|c|c|}
\hline \multirow[b]{3}{*}{ Sources $^{\mathrm{z}}$} & \multirow[b]{2}{*}{$\mathrm{N}$ rate } & \multirow[b]{2}{*}{$S$ rate } & \multicolumn{2}{|c|}{ Canopy diam } & \multirow{3}{*}{$\frac{\frac{\text { Leaf greenness }}{12 \text { WAT }}}{\text { (SPAD value) }}$} \\
\hline & & & $4 \mathrm{WAT}$ & $12 \mathrm{WAT}$ & \\
\hline & \multicolumn{2}{|c|}{$(1 \mathrm{~b} / \mathrm{acre})^{\mathrm{y}}$} & \multicolumn{2}{|c|}{ (inches) $^{\mathrm{y}}$} & \\
\hline Control & 0 & 0 & 11.7 & 13.1 & 43.8 \\
\hline $\mathrm{AN}$ & 50 & 0 & 10.9 & 14.1 & 44.3 \\
\hline AS & 50 & 57 & 11.1 & 13.0 & 45.0 \\
\hline ASN & 50 & 27 & 11.2 & 13.5 & 46.7 \\
\hline PCAS & 50 & 57 & 11.3 & 13.4 & 44.9 \\
\hline Elemental S & 0 & 57 & 11.2 & 13.2 & 43.8 \\
\hline \multicolumn{3}{|c|}{ Significance $(P<0.05)$} & NS & NS & NS \\
\hline
\end{tabular}

${ }^{2} \mathrm{AN}=$ ammonium nitrate, $\mathrm{AS}=$ ammonium sulfate, $\mathrm{ASN}=$ ammonium sulfate nitrate, $\mathrm{PCAS}=$ polymer-coated $\mathrm{AS}$, SPAD $=$ soil plant analysis development

${ }^{y} 1 \mathrm{lb} /$ acre $=1.1209 \mathrm{~kg} \cdot \mathrm{ha}^{-1}, \mathrm{l}$ inch $=2.54 \mathrm{~cm}$

Ns, Not significant at $P<0.05$. 
Planting dates during each respective season were 11 Oct. 2007 and 15 Oct. 2008. Bare-root transplants from certified nurseries in Nova Scotia, Canada, were set 15 inches apart in double rows. Double rows were separated 15 inches apart. Sprinkler irrigation was used $8 \mathrm{~h}$ per day for $10 \mathrm{~d}$ to establish 'Strawberry Festival' transplants. After establishment, plants were irrigated twice per day with one irrigation in the morning between 08:00 and 09:00 $\mathrm{HR}$ and another in the early afternoon from 13:00 to 14:00 HR. Irrigation cycles were $15 \mathrm{~min}$ from October to mid-November, $30 \mathrm{~min}$ from midNovember to early December, and $45 \mathrm{~min}$ from early December to the end of the season. Planted plots received $\approx 120 \mathrm{lb} /$ acre of $\mathrm{N}$ through the drip lines during the season in daily injections with the last irrigation cycle using calcium nitrate $(9 \% \mathrm{~N})$ as the fertilizer source. From October to mid-November, the drip-injected $\mathrm{N}$ fertilization rate was $0.6 \mathrm{lb} /$ acre per day, from mid-November to midDecember, it was increased to 0.75 $\mathrm{lb} / \mathrm{acre}$ per day, and from midDecember to early March, the daily $\mathrm{N}$ rate was $1.0 \mathrm{lb} /$ acre per day. Fertilization occurred during the first daily irrigation cycle. $S$ was not added through the drip fertilization. Other drip-applied plant nutrients were supplied to the crop following statewide recommendations (Peres et al., 2006).

Strawberry canopy plant diameters were measured at 4 and 12 weeks after transplanting (WAT) perpendicular to the direction of the rows, using five randomly selected plants per plot but avoiding border plants. The same five plants per plot were sampled during the two diameter observations. Greenness of leaves was measured at 12 WAT with a handheld color meter (SPAD-502; Minolta, Ramsey, NJ), which provides a numerical soil plant analysis development (SPAD) value, ranging from 0 to 80 , where $0=$ white and $80=$ dark green. The same plants used for plant diameter were used to obtain the greenness data and two readings were taken from two of the newest mature leaves on the top of the plant canopies. Early and total marketable fruit weights were collected starting at 10 WAT using every plant of each plot. Early marketable fruit weight was defined as the cumulative marketable weight of the first 10 harvests, whereas total marketable fruit weight consisted of 22 harvests during each season. Fruit were harvested Mondays and Thursdays of each week for 11 weeks, starting on the 3rd week in December of each season. A marketable fruit was defined as a fruit without visible blemishes with at least $75 \%$ red skin. Early and total weights per fruit were determined by dividing the marketable fruit weight of each treatment by its corresponding fruit number. Fertilizer source effects were examined for significance $(P<0.05)$ with the general linear model (Statistix Analytical Software, Tallahassee, FL). Means were compared with a Fisher's protected least significance difference test at the $5 \%$ significance level.

\section{Results and discussion}

There were no significant season by treatment interactions for all examined variables, thus data from the two seasons were combined for analysis $(P$ $<0.05)$. The treatments did not affect canopy diameters at 4 and 12 WAT, and leaf greenness at 12 WAT $(P>$ $0.05)$. Canopy diameter at 4 WAT ranged between 10.9 and 11.7 inches, whereas canopy diameter at 12 WAT was between 13.0 and 14.1 inches (Table 1). Application of the treatments influenced early and total marketable strawberry fruit number. For early fruit number, the highest values were found in plots treated with AS and elemental $\mathrm{S}$ with values of 191,700 and 194,700 fruit/acre, which were $\approx 6.7 \%$ and $8.3 \%$ higher than the nontreated control (Table 2). There were no significant differences among the other remaining treatments. The highest total fruit numbers were obtained in plots treated with AS, ASN, PCAS, and elemental $S$, ranging between 478,300 and 481,800 fruit/ acre. There was no significant difference in total fruit numbers between the nontreated control and AN with less than 460,000 fruit/acre (Table 2).

Early and total marketable fruit weights were significantly influenced by the treatments. Plots treated with elemental S, PCAS, ASN, and AS had the highest early marketable fruit weights, with values ranging between 6.2 and 6.8 tons/acre, whereas the lowest value was found in the nontreated plots, where 5.0 tons/acre of fruit were produced (Table 2). In comparison with the nontreated control plots, all the preplant fertilization programs improved early marketable fruit weight, with $\mathrm{AN}, \mathrm{AS}, \mathrm{ASN}$, PCAS, and elemental $S$ increasing by $0.6,1.2,1.8,1.5$, and 1.5 tons/acre, respectively. Total marketable fruit weights were maximized in plots receiving preplant AS, ASN, PCAS, and elemental S, ranging between 15.6 and 16.6 tons/acre. There was no

Table 2. Effects of preplant nitrogen $(\mathrm{N})$ and sulfur $(\mathrm{S})$ sources on strawberry early and total marketable fruit number and weight, and early and total weight per fruit in 2007-08 and 2008-09 at Balm, FL.

\begin{tabular}{|c|c|c|c|c|c|c|c|c|}
\hline \multirow[b]{3}{*}{ Sources $^{\mathrm{z}}$} & \multirow[b]{2}{*}{$\mathrm{N}$ rates } & \multirow{3}{*}{$\frac{S \text { rates }}{\mathrm{e})^{\mathrm{y}}}$} & \multicolumn{2}{|c|}{ Marketable fruit no. } & \multicolumn{2}{|c|}{ Marketable fruit wt } & \multicolumn{2}{|c|}{ Wt per fruit } \\
\hline & & & Early & Total & Early & Total & Early & Total \\
\hline & $(\mathrm{lb} / \mathrm{acre})^{\mathrm{y}}$ & & \multicolumn{2}{|c|}{$(1000 \text { fruit/acre })^{\mathrm{y}}$} & \multicolumn{2}{|c|}{$(\text { tons } / \text { acre })^{\mathrm{y}}$} & \multicolumn{2}{|c|}{$(g)^{y}$} \\
\hline $\mathrm{AN}$ & 50 & 0 & $178.2 \mathrm{~b}$ & $458.0 \mathrm{c}$ & $5.6 \mathrm{~b}$ & $14.6 \mathrm{~b}$ & $28.5 \mathrm{~b}$ & 28.9 \\
\hline AS & 50 & 57 & $191.7 \mathrm{a}$ & $487.9 \mathrm{a}$ & $6.2 \mathrm{ab}$ & $16.5 \mathrm{a}$ & $29.4 \mathrm{ab}$ & 30.7 \\
\hline ASN & 50 & 27 & $180.1 \mathrm{~b}$ & $492.0 \mathrm{a}$ & $6.8 \mathrm{a}$ & $16.2 \mathrm{a}$ & $34.3 \mathrm{a}$ & 29.9 \\
\hline \multicolumn{3}{|c|}{ Significance $(P<0.05)$} & * & * & * & * & * & NS \\
\hline
\end{tabular}

${ }^{\mathrm{z}} \mathrm{AN}=$ ammonium nitrate, $\mathrm{AS}=$ ammonium sulfate, $\mathrm{ASN}=$ ammonium sulfate nitrate, $\mathrm{PCAS}=$ polymer-coated AS.

${ }^{y} \mathrm{l} \mathrm{lb} /$ acre $=1.1209 \mathrm{~kg} \cdot \mathrm{ha}^{-1}, \mathrm{l}$ fruit/acre $=2.471 \mathrm{l}$ fruit/ha, $\mathrm{l}$ ton/acre $=2.2417 \mathrm{t} \cdot \mathrm{ha}^{-1}, \mathrm{l} \mathrm{g}=0.0353 \mathrm{oz}$.

'Values followed by the same letters do not differ at the $5 \%$ significance lever, according to Fisher's least significant difference test.

NS, ${ }^{*}$ Not significant and significant at $P<0.05$, respectively. 
difference between the total fruit weights obtained in the control and AN-treated plots, which averaged 14.7 tons/acre. Application of preplant fertilizers significantly influenced the early strawberry weights per fruit, but not the total weights per fruit (Table 2). The largest early fruit were obtained in plots treated with ASN, PCAS, AS, and elemental S, ranging between 29.4 and $34.3 \mathrm{~g}$ per fruit. The nontreated control had the smallest fruit, with an average weight of $25.3 \mathrm{~g}$ per fruit. These weight per fruit differences disappeared along the season, as shown by the lack of significant differences among treatments for total weight per fruit, which averaged $30.0 \mathrm{~g}$ per fruit.

These results supported two major findings from the standpoint of preplant nutrient management for strawberry production in Florida sandy soils. First, the data indicated that the observed strawberry total yield increases can be attributed exclusively to the use of preplant fertilizer sources containing $S$. This finding was demonstrated with the preplant application of elemental $S$, where total fruit weight and number did not differ from those treated with $\mathrm{N}$ and $\mathrm{S}$. The fertilizer sources AS, ASN, and PCAS had between 27 or $57 \mathrm{lb} /$ acre of $\mathrm{S}$ and there were no significant differences on early and total fruit weights among plots treated with these sources, which suggested that $27 \mathrm{lb} /$ acre of $S$ might be sufficient to satisfy strawberry requirements. However, further research is needed to characterize the rate response of the crop to $S$. Second, there was a marginal effect of adding $\mathrm{N}$ to preplant fertilizer formulas for strawberry production in Florida. Application of AN improved early fruit weight in relation to the nontreated control, but failed to reach the same early fruit weight values than those treatments containing $S$. Furthermore, that effect disappeared as the strawberry season progressed with no AN effect on total fruit weight. The latter conclusion agrees with previous research reported by Albregts et al. (1991a) and Santos and Whidden (2007), who indicated that preplant application $\mathrm{N}$ had no effect on total strawberry yields, regardless of the used $\mathrm{N}$ source. This research may lead to a more appropriate use of $\mathrm{N}$ for strawberry production in Florida, minimizing the nitrate-leaching potential in high sandy soils. Additionally, if a preplant rate of $50 \mathrm{lb} /$ acre of $\mathrm{N}$ and a price of $\$ 500 /$ ton of $\mathrm{AN}$ are assumed, that would mean savings of $\$ 12.50 /$ acre plus the cost of application equipment and labor. At the same time, $S$ nutrition should be added to regular strawberry fertilization programs.

\section{Literature cited}

Albregts, E.E., C.M. Howard, and C.K. Chandler. 1991b. Slow-release fertilizers for strawberry fruit production. Proc. Florida State Hort. Soc. 104:244-245.

Albregts, E.E., G.A. Clark, C.D. Stanley, F.S. Zazueta, and A.G. Smajstrla. 199la. Preplant fertilization of fruiting microirrigated strawberry. HortScience 26:11761177.

Cassman, K.G., A. Dobermann, and D.T. Walters. 2002. Agroecosystems, nitrogenuse efficiency, and nitrogen management. Ambio 31:132-140.

Ceccotti, S.P., R.J. Morris, and D.L. Messick. 1998. A global overview of the sulphur situation: Industry's background, market trends, and commercial aspects of sulphur fertilizers, p. 175-202. In: E. Schnug (ed.). Sulphur in agroecosytems. Kluwer Academic, Dordrecht, The Netherlands.

Finkl, C.W. and R.H. Charlier. 2003. Sustainability of subtropical coastal zones in southeastern Florida: Challenges for urbanized coastal environments threatened by development, pollution, water supply, and storm hazards. J. Coast. Res. 19:934-943.

Fixen, P.E. and F.B. West. 2002. Nitrogen fertilizers: Meeting contemporary challenges. Ambio 31:169-176.

Florida Department of Environmental Protection. 2008. Integrated water quality assessment for Florida: 2008 305(b) report and 303(d) list update. 26 Nov. 2008. <http://www.dep.state.fl.us/water/ docs/2008_Integrated_Report.pdf>.

Florida Springs Task Force. 2000. Florida's springs: Strategies for protection and restoration. 26 Nov. 2008. <http://www. dep.state.fl.us/springs/reports/index. htm>.

Food and Agriculture Organization of the United Nations. 2008. FAOSTAT. 26 Nov. 2008. <http://faostat.fao.org/site/ $567 /$ default.aspx\#ancor>

Guertal, E.A. 2000. Preplant slow-release nitrogen fertilizers produce similar bell pepper yields as split applications of soluble fertilizer. Agron. J. 92:388-393.

Guertal, E.A. 2009. Slow-release nitrogen fertilizers in vegetable production: A review. Hort Technology 19:16-19.

Heeb, A., B. Lundegardh, G. Savage, and T. Ericsson. 2006. Impact of organic and inorganic fertilizers on yield, taste, and nutritional quality of tomatoes. J. Plant Nutr. Soil Sci. 169:535-541.

Hochmuth, G. and K. Cordasco. 2009. A summary of $\mathrm{N}$ and $\mathrm{K}$ research with strawberry in Florida. 20 July 2009. <http://edis. ifas.ufl.edu/pdffiles/CV/CV22900.pdf>.

Locascio, S.J. and F.G. Martin. 1985. Nitrogen source and application timing for trickle irrigated strawberries. J. Amer. Soc. Hort. Sci. 110:820-823.

Mylavarapu, R.S. 2009. UF/IFAS extension soil testing laboratory (ESTL) analytical procedures and training manual. 12 Sept. 2009. <http://edis.ifas.ufl.edu/ SS312>.

Pavlista, A.D. 2005. Early-season application of sulfur fertilizers increase potato yield and reduce tuber defects. Agron. J. 97:599-603.

Peres, N.A., J.F. Price, W.M. Stall, C.K. Chandler, S.M. Olson, T.G. Taylor, S.A. Smith, and E.H. Simonne. 2006. Strawberry production in Florida, p. 375-382. In: S.O. Olson and E.H. Simonne (eds.). Vegetable production handbook for Florida, 2006-2007. Inst. Food Agr. Sci., Univ. Florida, Gainesville.

Rhoads, F.M. and S.M. Olson. 2000. Cabbage response to sulfur source and nitrogen rate. Soil Crop Sci. Soc. Florida 60:20-22.

Santos, B.M. and A.J. Whidden. 2007. Nitrogen fertilization of strawberry cultivars: Is preplant starter fertilizer needed? 26 Nov. 2008. <http://edis.ifas.ufl.edu/ pdffiles/HS/HS37000.pdf>.

Scherer, H.W. 2001. Sulphur in crop production. Eur. J. Agron. 14:81-111.

Susila, A.D. 2001. Sulfur nutrition requirement for drip irrigated tomato, cabbage, and pepper. Univ. Florida, Gainesville, $\mathrm{PhD}$ diss.

Tabatabai, M.A. 1984. Importance of sulphur in crop production. Biogeochemistry $1: 45-62$.

U.S. Department of Agriculture. 2008. Vegetables: 2007 summary. 2 May 2008. <http://usda.mannlib.cornell.edu/usda/ current/VegeSumm/VegeSumm-01-252008.pdf>. 